\title{
Infection prevention in personal services settings: Evidence, gaps and the way forward
}

\author{
A Popalyar ${ }^{1}$, J Stafford ${ }^{2}$, T Ogunremi' ${ }^{1}, K$ Dunn ${ }^{1 *}$
}

\begin{abstract}
Background: Personal services is a continuously evolving industry that encompasses a variety of aesthetic treatments and personal enhancement services. Personal services are an important public health concern because delivery of service may pose potential health risks for both clients and workers. To date, there is a lack of evidence on the specific infection risks involved with personal services and the magnitude of these risks. While guidance and regulation of personal services settings do exist, they appear in varying degrees and complexity across Canada.

Objectives: To summarize relevant literature on the risk of infections related to personal services; conduct an environmental scan of current provincial and territorial guidance and regulations; identify key risk mitigation measures; and summarize gaps and challenges.
\end{abstract}

Methods: A working group of national experts in the field of infection prevention and control was established for consultation on key issues. A narrative literature review was conducted to summarize findings from relevant articles. Key questions and a literature search strategy were developed and articles were screened and critically appraised for eligibility. An environmental scan of key guidelines was also conducted to identify relevant legislation and guidance.

Findings from both the narrative review and environmental scan were summarized to inform guidance and identify gaps.

Findings: The review of the literature identified factors associated with increased risk of infection including inadequate training of personal services workers and non-compliance with established infection prevention principles. The environmental scan demonstrated that some guidelines have been developed by provincial/territorial ministries of health utilizing basic, generally accepted infection prevention principles. The established body of evidence that informs infection prevention and control recommendations is valid for health care settings; however, there are factors to consider in extracting and applying such guidance to personal services settings. Major gaps and challenges remain in supporting both the advancement of infection prevention guidance and the development of enhanced regulatory frameworks, applicable to personal services settings in Canada.

Conclusion: This review involved a comprehensive examination of relevant literature and provides a summary of issues addressing the risk of infection in personal services settings. There is a paucity of high quality evidence to support guidance, and findings reveal the need for further investigation and enhanced awareness of public health risks associated with personal services. Nonetheless, these findings can inform future research and the development of infection prevention and control guidelines and recommendations for such settings.

Suggested citation: Popalyar A, Stafford J, Ogunremi T, Dunn K. Infection prevention guidance for personal services settings: Evidence, gaps and the way forward. Can Commun Dis Rep 2019;45(1):1-11. https://doi. org/10.14745/ccdr.v45i01a01
This work is licensed under a Creative Commons Attribution 4.0 International License.

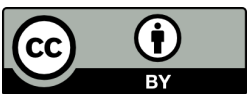

Affiliations

${ }^{1}$ Centre for Communicable Diseases and Infection Control, Public Health Agency of Canada, Ottawa, ON

2 Infection Prevention and Control Acute Care, Department of Health, Government of New Brunswick, Fredericton, NB

*Correspondence:

kathleen.dunn@canada.ca

Keywords: personal services, infection, prevention, risk mitigation 


\section{Introduction}

Personal services is a continuously evolving industry that encompasses a variety of aesthetic treatments and personal enhancement services, from non-invasive (such as hair and nail services) to invasive procedures such as microneedling and other body modification procedures. Many of these services intentionally or accidentally penetrate the body's defences, posing an infection risk to clients and personal services workers.

There is little information on the infection risks specifically associated with these services. In addition, there is no national surveillance system related to complications of the personal services industry in Canada. While guidance and regulation of personal services settings do exist, the degree and complexity varies across Canada. With a lack of evidence related to disease acquisition in personal services settings, general principles of infection prevention are applied; these may not be directly applicable to the industry.

The objectives of this article are to summarize the available relevant literature on the risk of infections related to personal services; conduct an environmental scan of current provincial/ territorial ministry of health guidance and regulations; outline generally accepted infection prevention principles relevant to personal services settings; and summarize major gaps and challenges. This article is intended to bring greater awareness from a public health perspective and be a resource for those considering the development of guidelines or regulations in this area.

A review of practice guidelines, recommendations, position papers, produced by personal services and/or public health professional associations or by educational programs is beyond the scope of this article.

\section{Methods}

\section{Expert Working Group}

In 2013, an expert working group was established to inform the Public Health Agency of Canada (PHAC) of issues associated with personal services and to provide infection prevention guidance for this setting. Expertise from the field included public health nurses and inspectors and infection prevention and control professionals from Nova Scotia, New Brunswick, Ontario, Manitoba and Alberta. The expert working group reviewed findings from the literature search and environmental scan.

\section{Literature review}

A narrative literature review was conducted to determine and summarize findings from relevant studies on the risk of infections related to personal services and inform the development of guidance. Key questions addressed prevalence, infection risk factors and infection prevention strategies for the three categories of personal services: piercing; other invasive services; and non-invasive services. The Health Library (Health Canada) undertook a comprehensive literature search using PubMed, Embase, Global Health, Ovid MEDLINE, Ovid MEDLINE Daily and Ovid OLDMEDLINE databases for studies published from January 1999 to December 2016.

The search was limited to studies in English and French with no filters applied, which would limit retrieval by study design. The full texts of all retrieved studies were manually screened to identify studies that reported on the receipt of one or more of the following categories of services:

- Body modification (i.e., ear/body piercing, body/eyeball tattooing, micropigmentation, scarification, tongue splitting, beading, jewellery implants, ocular jewellery, branding)

- Injections (i.e., fillers)

- Cosmetology (i.e., aesthetics, hair dressing/barber services, shaving, microdermal abrasion, facials, artificial nails, manicures, pedicures, make-up, face painting, waxing, electrolysis); and/or

- Other personal services (i.e., health spa/skin clinic, mud/ steam bath, laser service including hair removal/skin resurfacing, massage, tanning, aromatherapy, teeth whitening, colonic irrigation, flotation tanks/water therapy)

AND the development of one or more of the following:

- Skin/soft tissue infection

- Bloodborne infection (e.g., hepatitis B, hepatitis C, HIV, other); and/or

- Systemic infection (e.g., endocarditis, septicemia, other)

\section{Environmental scan}

An environmental scan of ministry of health websites was conducted to identify provincial and territorial guidelines, standards and regulations to do with personal services.

Guiding principles for infection prevention and control, as applicable to personal service settings, were identified and summarized.

\section{Summary of findings}

\section{Expert Working Group}

Challenges and gaps identified by public health inspectors and infection prevention and control professionals highlighted the need for increased awareness as well as improved guidance and regulations. 


\section{Literature review}

Of the 729 papers identified for preliminary screening, 555 were reviews or abstracts and were therefore excluded. A further 92 papers did not meet the search criteria outlined in the scope. A critical appraisal of the remaining 82 studies was accomplished using the PHAC Infection Prevention and Control Guidelines Critical Appraisal Tool Kit (1), and a further 31 papers were eliminated due to flaws in methodology $(n=16)$ or analysis of results $(n=15)$. This resulted in a total of 51 papers on the risk of infections related to personal services.

\section{Risk of infection and transmission}

The risks identified in the literature were quite varied. Information relevant to infection risks and the magnitude of these risks specific to Canadian personal services settings were limited however, a number of studies identified factors associated with increased risk of infection in personal services settings in other countries:

- Inadequate training and skill level of personal services workers (resulting in poor infection prevention control practices) $(2,3)$

- Poor or non-compliance with generally established infection prevention practices (resulting in individual cases or wider outbreaks of infection) (4-7)

Specific findings related to breaches or non-compliance with recommended infection practices include:

- Improper glove use (8)

- Improper cleaning of the environment $(9,10)$

- Improper cleaning, disinfection and sterilization of tools or equipment $(2,7,8,10-20)$

- Use of non-sterile instruments for invasive procedures $(8,17-20)$

- Use of contaminated water, ink, supplies or equipment $(6,7,21-32)$

- Pre-existing health status of the clients (33-39)

- Failure to provide adequate after care instructions $(40,41)$

- Deficiencies in the physical layout and inadequate infection prevention and control practices, including lack of hand washing facilities and/ or with no potable water (8)

Studies showed that infections associated with personal services may be bacterial $(38,42-46)$, viral (47-52) or fungal (53). The risk for transmission of bloodborne viruses within personal services settings is impacted by knowledge of and/or adherence to effective, established infection prevention practices (54-58). Specific risk factors associated with exposure to bloodborne infections during personal services procedures include:
- Potential contact with blood when sharps containers are not placed within reach, leading to unnecessary handling of contaminated sharps and injuries; improper disposal of sharps, by, for example, repackaging used sharps or discarding them in the regular garbage

- Cross-contamination of instruments and surfaces

- Re-use of disposable instruments and equipment such as razors and styptic pencils

- Inadequate disinfection and sterilization of equipment

- Inadequate management of cuts and abrasions on personal services workers

- Inconsistent hand hygiene and glove use

- Lack of knowledge about appropriate procedures and routes of transmission of bloodborne pathogens

- $\quad$ Lack of vaccine-induced protection (e.g., for hepatitis B)

\section{Environmental scan}

The environmental scan was limited to provincial/territorial ministry of health websites to identify relevant legislation, regulations and approved guidelines, practices and standards. Guidance and regulations for personal services settings exist in varying degrees and complexity across Canada (Table 1). A review of practice guidelines, recommendations, position papers, etc. produced by personal services and/or public health professional associations or by educational programs was beyond the scope of the scan.

Table 1: Summary of published provincial and territorial personal services guidelines, standards, protocols, acts and regulations

\begin{tabular}{|c|c|c|}
\hline $\begin{array}{l}\text { Province/ } \\
\text { territory }\end{array}$ & $\begin{array}{c}\text { Guidelines, } \\
\text { standards, } \\
\text { protocols and/or } \\
\text { other }\end{array}$ & $\begin{array}{c}\text { Acts, regulations and/ } \\
\text { or bylaws }\end{array}$ \\
\hline $\begin{array}{l}\text { Newfoundland } \\
\text { and Labrador }\end{array}$ & N/A & $\begin{array}{l}\text { Personal Services Act, } \\
2012 \text { (59) }\end{array}$ \\
\hline $\begin{array}{l}\text { Prince Edward } \\
\text { Island }\end{array}$ & $\begin{array}{l}\text { Guidelines for Tanning } \\
\text { Salon Owners and } \\
\text { Operators, } 2011(60)^{a}\end{array}$ & $\begin{array}{l}\text { PEI Public Health Act, } \\
2018 \text { (61) }\end{array}$ \\
\hline Nova Scotia & $\begin{array}{l}\text { Salon and Spa } \\
\text { Compliance } \\
\text { Handbook, no date } \\
\text { (62) }\end{array}$ & $\begin{array}{l}\text { Safe Body Art Act, } 2011 \\
\text { (63) } \\
\text { Health Protection Act, } \\
2016 \text { (64) } \\
\text { Safe Body Art } \\
\text { Regulations, } 2018 \text { (65) }\end{array}$ \\
\hline New Brunswick & $\mathrm{N} / \mathrm{A}$ & $\begin{array}{l}\text { New Brunswick Bill } 56 \\
\text { Public Health Act, } 1998 \\
\text { (66) }\end{array}$ \\
\hline Quebec & $\begin{array}{l}\text { Tattooers and Piercers: } \\
\text { Protect Your Client and } \\
\text { Yourself Against HIV } \\
\text { and Hepatitis B and } \\
\text { C,1999 (67) }\end{array}$ & N/A \\
\hline
\end{tabular}


Table 1 (continued): Summary of published provincial and territorial personal services guidelines, standards, protocols, acts and regulations

\begin{tabular}{|c|c|c|}
\hline $\begin{array}{l}\text { Province/ } \\
\text { territory }\end{array}$ & $\begin{array}{l}\text { Guidelines, standards, } \\
\text { protocols and/or other }\end{array}$ & $\begin{array}{l}\text { Acts, regulations } \\
\text { and/or bylaws }\end{array}$ \\
\hline Ontario & $\begin{array}{l}\text { Infection Prevention and } \\
\text { Control Best Practices for } \\
\text { Personal Services Settings, } 2009 \\
\text { (68) } \\
\text { Infection Prevention and } \\
\text { Control Disclosure Protocol, } \\
2018 \text { (69) } \\
\text { Infection Prevention and } \\
\text { Control Complaint Protocol, } \\
2018 \text { (70) } \\
\text { Personal Service Settings } \\
\text { Guideline, } 2018 \text { (71) } \\
\text { The Ontario Public Health } \\
\text { Standards: Requirements } \\
\text { for Programs, Services, and } \\
\text { Accountability, } 2018 \text { (72) }\end{array}$ & $\begin{array}{l}\text { Health Promotion } \\
\text { and Protection and } \\
\text { Promotion Act, } \\
\text { Ontario Regulation } \\
\text { 136/18: Personal } \\
\text { Service Settings, } \\
2018 \text { (73) }\end{array}$ \\
\hline Manitoba & $\begin{array}{l}\text { Personal Services Facility } \\
\text { Guideline, } 2013 \text { (74) }\end{array}$ & N/A \\
\hline Saskatchewan & $\begin{array}{l}\text { Personal Service Facility Best } \\
\text { Management Practices, } 2014 \\
\text { (75) }\end{array}$ & $\begin{array}{l}\text { The Health Hazard } \\
\text { Regulations, } 2002 \\
\text { (76) }\end{array}$ \\
\hline Alberta & $\begin{array}{l}\text { Health Standards and } \\
\text { Guidelines for Tattooing, } 2002 \\
\text { (77) } \\
\text { Health Standards and } \\
\text { Guidelines for Body and Ear } \\
\text { Piercing, } 2002 \text { (78) } \\
\text { Health Standards and } \\
\text { Guidelines for Barbering and } \\
\text { Hairstyling, } 2002 \text { (79) } \\
\text { Health Standards and } \\
\text { Guidelines for Esthetics, } 2002 \\
\text { (80) } \\
\text { Health Standards and } \\
\text { Guidelines for Electrolysis, } 2002 \\
\text { (81) }\end{array}$ & $\begin{array}{l}\text { Public Health } \\
\text { Personal Services } \\
\text { Regulation, } 2003 \\
\text { (82) }\end{array}$ \\
\hline $\begin{array}{l}\text { British } \\
\text { Columbia }\end{array}$ & $\begin{array}{l}\text { Guidelines for Personal Services } \\
\text { Establishments, } 2017 \text { (83) } \\
\text { Guidelines For Body } \\
\text { Modification, } 2017 \text { (84) } \\
\text { Guideline for Personal Services } \\
\text { Offered at Tradeshows, } 2016 \\
\text { (85) } \\
\text { Guidelines for Floatation Tanks, } \\
2016 \text { (86) } \\
\text { Laser Hair Removal Devices: } \\
\text { Safety Guidelines for Owners/ } \\
\text { Operators, } 2005 \text { (87) } \\
\text { Microblading Services in } \\
\text { Personal Service Establishments } \\
\text { - Fact Sheet for Operators, } \\
2017 \text { (88) }\end{array}$ & $\begin{array}{l}\text { Public Health } \\
\text { Act, Regulated } \\
\text { Activities } \\
\text { Regulation, } 2011 \\
\text { (89) }\end{array}$ \\
\hline
\end{tabular}

Table 1 (continued): Summary of published provincial and territorial personal services guidelines, standards, protocols, acts and regulations

\begin{tabular}{|l|l|l|}
\hline $\begin{array}{c}\text { Province/ } \\
\text { territory }\end{array}$ & $\begin{array}{l}\text { Guidelines, standards, } \\
\text { protocols and/or other }\end{array}$ & $\begin{array}{c}\text { Acts, regulations } \\
\text { and/or bylaws }\end{array}$ \\
\hline Yukon & $\begin{array}{l}\text { Personal Service Premises } \\
\text { Inspection Model, 2013 } \\
(90)\end{array}$ & $\begin{array}{l}\text { Public Health Act } \\
- \text { Personal Service } \\
\text { Establishment } \\
\text { Regulations, 1984 (91) }\end{array}$ \\
\hline $\begin{array}{l}\text { Northwest } \\
\text { Territories }\end{array}$ & $\begin{array}{l}\text { Standards for Personal } \\
\text { Service Establishments, } \\
2012 \text { (92) }\end{array}$ & $\begin{array}{l}\text { Public Health Act } \\
\text { - Personal Services } \\
\text { Establishment } \\
\text { Regulations, 2013 (93) }\end{array}$ \\
\hline Nunavut & N/A & $\begin{array}{l}\text { Public Health Act, 2016 } \\
\text { (94) } \\
\text { Barber Shops and } \\
\text { Beauty Salons } \\
\text { Regulations, 1990 (95) }\end{array}$ \\
\hline
\end{tabular}

\section{General risk mitigation measures}

The scope of personal services is very broad and different services and settings may require different infection prevention guidance. Generally accepted key measures that minimize infection risk are summarized in Table 2. Consistent application of infection prevention practices and precautions help prevent the acquisition and transmission of infections. The general infection prevention principles outlined in Table 2 are not comprehensive and are based on core infection prevention principles as identified in the PHAC guideline: Routine Practices and Additional Precautions for Preventing the Transmission of Infection in Healthcare Settings (96).

\section{Gaps and challenges}

Following the review of findings from the narrative review and environmental scan as well as discussions with the expert working group, a number of gaps and challenges were identified. These are summarized in Table 3. 
Table 2: General infection prevention principles to mitigate risk of exposure to infections in personal services settings

\begin{tabular}{|c|c|}
\hline Risk Mitigation Measure & Additional Context \\
\hline Administrative controls & $\begin{array}{l}\text { - Provide an infrastructure of protocols and practices intended to prevent the risk of infection to personal services } \\
\text { workers and clients in personal services settings } \\
\text { - Administrative controls include infection prevention policies and procedures; education and training (along } \\
\text { with readily available resources such as instructions and manuals); proper use of equipment and instruments; } \\
\text { monitoring compliance with infection prevention practices; appropriate occupational health and safety practices } \\
\text { (e.g., worker immunization); and documentation and record keeping (e.g., records of disinfection and sterilization) } \\
\text { in accordance with municipal and/or provincial/territorial standards and legislation }\end{array}$ \\
\hline Risk assessment & $\begin{array}{l}\text { - Must be performed before undertaking any personal service activity to evaluate the risk of infection or cross- } \\
\text { contamination associated with an activity and to implement appropriate prevention measures } \\
\text { - Includes determining the potential for contact with blood, body fluids and non-intact skin for the worker or client, } \\
\text { exposure to mucous membranes and exposure to contaminated equipment or surfaces }\end{array}$ \\
\hline Hand hygiene & $\begin{array}{l}\text { - Single most important measure for preventing the transmission of microorganisms in all settings } \\
\text { - Should be performed (as recommended in the PHAC Hand Hygiene Practices in Healthcare Settings guideline } \\
\text { and local or provincial/territorial guidelines) using either an alcohol-based hand rub or liquid soap and water if } \\
\text { hands are visibly soiled ( } 97) \\
\text { - Gloves are not a substitute for hand hygiene }\end{array}$ \\
\hline $\begin{array}{l}\text { Environmental cleaning and } \\
\text { disinfection }\end{array}$ & $\begin{array}{l}\text { - Helps reduce the contamination of surfaces, decreasing the risk of transmission of microorganisms that may lead } \\
\text { to infections in clients or workers } \\
\text { - Manufacturer's directions for use and contact times for cleaning and disinfection products must be followed } \\
\text { - Low-risk surfaces (e.g., tables covered with a single-use towel, hairdressing chairs or sinks for hair washing) are less } \\
\text { likely to contribute to an infection as they typically come into contact only with intact skin. These surfaces should } \\
\text { be cleaned immediately when they become visibly soiled and at least once per day (98) } \\
\text { - Higher-risk surfaces (e.g., manicure/pedicure tables not covered with a single-use towel, counters used to prepare } \\
\text { materials, equipment for procedures or foot baths) are more likely to be contaminated from contact with non- } \\
\text { intact skin and blood and/or other body fluids. These surfaces should be cleaned and disinfected between clients } \\
\text { and when surfaces are visibly soiled (98) }\end{array}$ \\
\hline $\begin{array}{l}\text { Single-use devices and } \\
\text { products }\end{array}$ & $\begin{array}{l}\text { - Single-use devices and products should be used wherever possible and, where applicable, lot numbers and expiry } \\
\text { dates should be checked prior to use } \\
\text { - Single-use devices and products must be discarded after one use: they must not be reprocessed, reused or kept } \\
\text { in the personal services setting for future use with either the same client or a different client }\end{array}$ \\
\hline $\begin{array}{l}\text { Reprocessing reusable } \\
\text { devices }\end{array}$ & $\begin{array}{l}\text { - Level of reprocessing required for a specific reusable device depends on the device's intended use and the risk of } \\
\text { infection to the client } \\
\text { - All reusable devices require meticulous cleaning prior to disinfection or sterilization } \\
\text { - Reusable devices used in the provision of services to clients must be reprocessed according to manufacturer } \\
\text { instructions for cleaning, disinfection and/or sterilization and should adhere to the most current reprocessing } \\
\text { standards from the Canadian Standards Association. In the absence of specific manufacturer's instructions, } \\
\text { decisions around reprocessing should be based on provincial/territorial best practice recommendations (96) or } \\
\text { determined based on Spaulding's classification (99) }\end{array}$ \\
\hline
\end{tabular}

Abbreviation: PHAC, Public Health Agency of Canada

Table 3: Gaps and challenges both related to infection prevention and outside the scope of infection prevention

Gap/Challenge
related to:

Related to infection prevention

\begin{tabular}{l|l} 
Setting & Health care guidelines and standards for infection prevention are not directly applicable to personal services settings
\end{tabular}

- Personal services settings serve a healthier client base compared to most health care settings

- Personal services settings are often small businesses; feasibility of implementing guidelines/standards is an important consideration

- The physical layout and design of these settings can contribute to infection prevention issues. Personal services are no longer only offered in traditional commercial settings; they now include mobile, home-based, mall kiosk and specialevent settings. There are limited guidelines and standards in this industry to address these issues directly. Where guidelines and standards do exist, they are mostly developed from the perspective of permanent commercial settings (e.g., stores in retail spaces) and may not be applicable to alternate settings

Limited and poor quality literature and data on risk of infection and the burden of illness associated with personal services settings

- No Canadian research published for infection prevention in personal services settings; data obtained from poor quality evidence such as case reports

Recommendations for cleaning and disinfection, including recommendations for products used to clean and disinfect, exist in varying degrees and complexities

- Practices for cleaning and disinfection are inconsistent

- Availability and purchase of standardized disinfection products can be a challenge in community practice

- A similar challenge exists for antiseptic products. Some settings wish to use alternative products that may not be appropriate for antisepsis 
Table 3 (continued): Gaps and challenges both related to infection prevention and outside the scope of infection prevention

\begin{tabular}{|c|c|}
\hline $\begin{array}{l}\text { Gap/Challenge } \\
\text { related to: }\end{array}$ & Context \\
\hline \multicolumn{2}{|c|}{ Related to infection prevention (continued) } \\
\hline \multirow[t]{2}{*}{$\begin{array}{l}\text { Infection prevention } \\
\text { education and training }\end{array}$} & $\begin{array}{l}\text { Education and training of workers on infection prevention is not feasible (or enforceable) in many personal services } \\
\text { settings }\end{array}$ \\
\hline & $\begin{array}{l}\text { Workplace and practice audits by personnel trained in infection prevention are often not available to personal } \\
\text { services settings }\end{array}$ \\
\hline \multicolumn{2}{|c|}{ Outside the scope of infection prevention } \\
\hline \multirow[t]{3}{*}{ Legal infrastructure } & $\begin{array}{l}\text { A consistent definition of personal services across jurisdictions is difficult to achieve as this is a continuously evolving } \\
\text { industry. Lists of procedures that can be offered in these settings exist; however they are quickly outdated and are } \\
\text { inconsistent across jurisdictions }\end{array}$ \\
\hline & $\begin{array}{l}\text { Jurisdictional guidance and/or regulation regarding acceptable procedures and standards may be limited for non- } \\
\text { regulated workers. There are questions around the type of procedures acceptable for delivery by personal services } \\
\text { workers versus delivery by health care professionals }\end{array}$ \\
\hline & $\begin{array}{l}\text { Health care professionals are providing services in medical spa settings; this has created a grey area for public health } \\
\text { inspectors. While the practice of the personal services worker falls under the jurisdiction of the professional regulatory } \\
\text { body, the service delivery setting itself can require public health inspection if located outside the mandate of a health } \\
\text { authority }\end{array}$ \\
\hline \multirow[t]{3}{*}{ Client safety } & $\begin{array}{l}\text { Chemicals and devices used in personal services settings can cause injuries such as those associated with the } \\
\text { application of energy (e.g., lasers, fat freezing, cryotherapy chambers, plasma pens) and injections (e.g., mesotherapy). } \\
\text { Health care organizations have protocols, procedures, and oversight in place to ensure devices and products are used } \\
\text { safely and to address any injuries; many personal services settings do not have this type of infrastructure }\end{array}$ \\
\hline & $\begin{array}{l}\text { Health Canada licences medical devices, products and chemicals that can be sold in Canada, but other substances that } \\
\text { may not be licensed for use in Canada are available for purchase internationally via the internet }\end{array}$ \\
\hline & $\begin{array}{l}\text { The public do not consistently have access to inspection reports that would assist them in their choice of personal } \\
\text { services setting }\end{array}$ \\
\hline \multirow{3}{*}{$\begin{array}{l}\text { Worker skill and } \\
\text { knowledge }\end{array}$} & There is uncertainty regarding scope of practice, in particular for workers without a professional regulatory body \\
\hline & $\begin{array}{l}\text { Many workers do not have formal standard education and training in the services they provide. They may be self- } \\
\text { taught or learn from another worker }\end{array}$ \\
\hline & $\begin{array}{l}\text { Most personal services settings require a license to operate, but not all workers have their practice regulated by a } \\
\text { professional college/association }\end{array}$ \\
\hline
\end{tabular}

\section{Discussion}

There are concerns about infection prevention in the personal services industry. This article describes some of the concerns from a public health perspective, based on published studies and an environmental scan of guidelines and regulations available on provincial/territorial ministry of health websites. In addition, the gaps and challenges presented are a preliminary list of major issues as identified by the external expert working group, and do not encompass the full breadth or complexity of issues faced by public health in general.

There were notable limitations with the results of the literature review, in terms of comparability and applicability of available evidence to the Canadian context of personal services settings. This includes challenges with the quality of evidence, and limitations to extraction of data from case reports, self-reports, laboratory sampling, medical records and survey questionnaires. General principles and core elements for infection prevention are available from an established and recognized body of evidence that informs recommendations for practice in health care settings; however, there are challenges when applying measures from one setting to another. When extracting specific guidance for health care settings and adapting to personal services settings, some measures may not be relevant or directly apply.

This industry continues to evolve, with emergence of new procedures and services across a range of personal settings. The majority of publications and reports available focused on tattooing and piercing; however, a number of areas of personal services have no published information. Examples include body modification (tongue splitting, branding and scarification), nail salons and laser device uses for body enhancement. There is a need for further investigation to reflect the broad range of services and risks for exposure and transmission of infections in the Canadian context.

The feasibility of implementing infection prevention standards can be a challenge for alternate small business settings. The physical layout and design of these settings can contribute to infection prevention issues, there is limited evidence and data on the risk of infection in these settings, practices for cleaning and disinfection are inconsistent, and worker education and training on infection prevention are also limited depending on available resources. 
In relation to the legal infrastructure, difficulties in defining personal services spill over into jurisdictional and regulatory issues and create grey areas in public health. Client safety is a major concern, particularly in the use of chemicals and devices in personal services settings. There is a need for standardized and consistent education and training of personal services workers.

While some organizations, such as the National Collaborating Centre on Environmental Health and the Canadian Institute of Public Health Inspectors, continue to examine and make efforts toward addressing issues related to personal services, further work is needed in this area. Canadian studies on infection prevention in personal services settings is recommended to provide information on the transmission pathways and risk of infections, and allow for assessment of burden of illness related to personal services settings in Canada. A continuously evolving industry also requires keeping an eye out for new services while working on legislation, regulation, guidelines, licensing and public education.

\section{Conclusion}

Personal services is a continuously evolving industry that encompasses a variety of aesthetic treatments and personal enhancement services, including procedures that range from non-invasive to more invasive, with associated risk of infection to clients and workers. This overview includes a summary of current regulations and guidelines across provincial and territorial jurisdictions. Findings were informed by the contribution of experts in the field, in addition to results from the narrative review and environmental scan.

Despite limitations to evidence on the specific infection risks associated with these services, reports and publications do indicate contributing factors and findings that can be used to inform risk mitigation strategies. At the current time, there is no established surveillance system for data related to complications associated with the personal services industry in Canada.

This summary identifies gaps and challenges to bring greater awareness from a public health perspective, and opportunities to address public health concerns through policy, regulation and guidelines, in an effort to promote and monitor best practices for the health of Canadians.

\section{Authors' statement}

AP - Data review, writing - original draft, review and editing JS - Data collection, data analysis and interpretation, writing review and editing TO - Writing - review and editing KD - Conceptualization, writing - review and editing, supervision and project administration

\section{Conflict of interest}

None.

\section{Contributors}

The authors would like to thank the following members of the expert working group for their subject matter expertise, contributions to the project that informed this article, and their input on former drafts of this article.

Jane Stafford (Chair), Department of Health, Government of New Brunswick, NB

Brenda Dyck, Winnipeg, MB

Carrie Fraser, Nova Scotia Department of Health and Wellness, Inverness, NS

Brenda Kwan, Durham Region Health Department, Whitby, ON

Christian Lapensee, Ottawa Public Health, Ottawa, ON

Jason MacDonald, Alberta Health \& Alberta Health Services,

Edmonton, $\mathrm{AB}$

Amy Pavletic, Middlesex-London Health Unit, London, ON

Cathie Walker, Elgin St Thomas Health Unit, London, ON

\section{Acknowledgements}

The authors thank Laurie O'Neil and Christine Weir for their project leadership, expertise on infection prevention and control, and for conducting initial literature reviews in consultation with members of the expert working group. The authors would like to thank Heidi Pitfield for subject matter expertise, review and contribution to discussions on the manuscript.

\section{Funding}

This work was supported by the Public Health Agency of Canada.

\section{References}

1. Moralejo D, Ogunremi T, Dunn K. Critical Appraisal Toolkit (CAT) for assessing multiple types of evidence. Can Commun Dis Rep 2017 Sep;43(9):176-81. DOI PubMed

2. Hellard M, Aitken C, Mackintosh A, Ridge A, Bowden S. Investigation of infection control practices and knowledge of hepatitis $C$ among body-piercing practitioners. Am J Infect Control 2003 Jun;31(4):21520. DOI PubMed

3. Lehman EJ, Huy J, Levy E, Viet SM, Mobley A, McCleery TZ. Bloodborne pathogen risk reduction activities in the body piercing and tattooing industry. Am J Infect Control 2010 Mar;38(2):130-8. DOI PubMed 
4. Keene WE, Markum AC, Samadpour M. Outbreak of Pseudomonas aeruginosa infections caused by commercial piercing of upper ear cartilage. JAMA 2004 Feb;291(8):981-5. DOI PubMed

5. Preda VA, Maley M, Sullivan JR. Mycobacterium chelonae infection in a tattoo site. Med J Aust 2009 Mar;190(5):278-9. PubMed

6. Scott-Lang VE, Sergeant A, Holme A. Mycobacteria introduced by tattoos. BMJ 2012;345:e8331. DOI

7. Rodríguez-Blanco I, Fernández LC, Suárez-Peñaranda JM, Pérez del Molino ML, Esteban J, Almagro M. Mycobacterium chelonae infection associated with tattoos. Acta Derm Venereol 2011 Jan;91(1):61-2. DOI PubMed

8. McLean M, D'Souza A. Life-threatening cellulitis after traditional Samoan tattooing. Aust N Z J Public Health 2011 Feb;35(1):27-9. DOI PubMed

9. Gira AK, Reisenauer AH, Hammock L, Nadiminti U, Macy JT, Reeves A, Burnett C, Yakrus MA, Toney S, Jensen BJ, Blumberg HM, Caughman SW, Nolte FS. Furunculosis due to Mycobacterium mageritense associated with footbaths at a nail salon. J Clin Microbiol 2004 Apr;42(4):1813-7. DOI PubMed

10. Stout JE, Gadkowski LB, Rath S, Alspaugh JA, Miller MB, Cox GM. Pedicure-associated rapidly growing mycobacterial infection: an endemic disease. Clin Infect Dis 2011 Oct;53(8):787-92. DOI PubMed

11. Winthrop KL, Abrams M, Yakrus M, Schwartz I, Ely J, Gillies D, Vugia DJ. An outbreak of mycobacterial furunculosis associated with footbaths at a nail salon. N Engl J Med 2002 May;346(18):1366-71. DOI PubMed

12. Amodio E, Di Benedetto MA, Gennaro L, Maida CM, Romano N. Knowledge, attitudes and risk of HIV, HBV and HCV infections in hairdressers of Palermo city (South Italy). Eur J Public Health 2010 Aug;20(4):433-7. DOI PubMed

13. Arulogun OS, Adesoro MO. Potential risk of HIV transmission in barbering practice among professional barbers in Ibadan, Nigeria. Afr Health Sci 2009 Mar;9(1):19-25. PubMed

14. Huijsdens XW, Janssen $M$, Renders NH, Leenders A, van Wijk P, van Santen Verheuvel MG, van Driel JK, Morroy G. Methicillin-resistant Staphylococcus aureus in a beauty salon, the Netherlands. Emerg Infect Dis 2008 Nov;14(11):1797-9. DOI PubMed

15. Ruddy $M$, Cummins $M$, Drabu Y. Hospital hairdresser as a potential source of cross-infection with MRSA. J Hosp Infect 2001 Nov;49(3):225-7. DOI PubMed

16. Vugia DJ, Jang Y, Zizek C, Ely J, Winthrop KL, Desmond E. Mycobacteria in nail salon whirlpool footbaths, California. Emerg Infect Dis 2005 Apr;11(4):616-8. DOI PubMed

17. Elegino-Steffens DU, Layman C, Bacomo F, Hsue G. A case of severe septicemia following traditional Samoan tattooing. Hawaii J Med Public Health 2013 Jan;72(1):5-9. PubMed

18. Ghorpade A. Lupus vulgaris over a tattoo mark--inoculation tuberculosis. J Eur Acad Dermatol Venereol 2003 Sep;17(5):569-71. DOI PubMed

19. Ghorpade A. Tattoo inoculation lupus vulgaris in two Indian ladies. J Eur Acad Dermatol Venereol 2006 Apr;20(4):476-7. DOI PubMed

20. Porter CJ, Simcock JW, MacKinnon CA. Necrotising fasciitis and cellulitis after traditional Samoan tattooing: case reports. J Infect 2005 Feb;50(2):149-52. DOI PubMed
21. Bedard B, Kennedy B, Escuyer $V$, Mitchell $K$, Duchin JS, Pottinger $P$, Hurst S, Bamberg W, LeBlanc P, Katz LM, MacCannell T, Noble-Wang J, O'Connell H, Kallen A, Jensen B, Nguyen DB, Kinzer MH; Centers for Disease Control and Prevention (CDC). Tattoo-associated nontuberculous mycobacterial skin infections--multiple states, 2011-2012. MMWR Morb Mortal Wkly Rep 2012 Aug;61(33):653-6. PubMed

22. Binić I, Janković A, Ljubenović M, Gligorijević J, Jančić S, Janković D. Mycobacterium chelonae infection due to black tattoo ink dilution. Am J Clin Dermatol 2011 Dec;12(6):404-6. DOI PubMed

23. Baumgartner A, Gautsch S. Hygienic-microbiological quality of tattoo-and permanent make-up colours. J Verbraucherschutz Lebensmsicherh 2011;6(3):319-25. DOI

24. Curcó N, Prat C, Tarroch X, Vives P. Cutaneous infection in a tattoo due to mycobacterium chelonae: a report of 2 cases and a review of the literature. Actas Dermosifiliogr 2012 Nov;103(9):840-3. DOI PubMed

25. Frew JW, Nguyen RT. Tattoo-associated mycobacterial infections: an emerging public health issue. Med J Aust 2015 Sep;203(5):223-3e. DOI PubMed

26. Goldman J, Caron F, de Quatrebarbes J, Pestel-Caron M, Courville P, Doré MX, Picard D, Duval-Modeste AB, Bravard P, Joly P. Infections from tattooing. Outbreak of Mycobacterium chelonae in France. BMJ 2010 Oct;341:c5483. DOI PubMed

27. Kay MK, Perti TR, Duchin JS. Tattoo-associated Mycobacterium haemophilum skin infection in immunocompetent adult, 2009. Emerg Infect Dis 2011 Sep;17(9):1734-6. DOI PubMed

28. Kotzen M, Sell J, Mathes RW, Dentinger C, Lee L, Schiff C, Weiss D. Using syndromic surveillance to investigate tattoo-related skin infections in New York City. PLoS One 2015 Jun;10(6):e0130468. DOI PubMed

29. Lollis BD, Kent RS. Cluster of nontuberculous mycobacteria skin infections from tattoos. Journal Article. DTIC Document, 2010. AFRL-SA-BR-TP-2010-0001 http://www.dtic.mil/dtic/tr/fulltext/u2/ a523390.pdf

30. Murray KF, Richardson LP, Morishima C, Owens JW, Gretch DR. Prevalence of hepatitis $C$ virus infection and risk factors in an incarcerated juvenile population: a pilot study. Pediatrics 2003 Jan;111(1):153-7. DOI PubMed

31. Ricciardo B, Weedon D, Butler G. Mycobacterium abscessus infection complicating a professional tattoo. Australas J Dermatol 2010 Nov;51(4):287-9. DOI PubMed

32. Suvanasuthi S, Wongpraparut C, Pattanaprichakul P, Bunyaratavej S. Mycobacterium fortuitum cutaneous infection from amateur tattoo. $J$ Med Assoc Thai 2012 Jun;95(6):834-7. PubMed

33. Ahluwalia R, Mills A, Cuthbertson D. An 'Avatar' infection: associated cellulitis in a type 2 diabetes patient following decorative tattooing. Pract Diabetes 2011;28(7):292. DOI

34. Barn P, Chen T. Infections associated with personal service establishments: piercing and tattooing. NCCEH. 2012. http://www. ncceh.ca/sites/default/files/PSE_Infections_Piercing_Tattooing_ May_2012.pdf

35. Alexandridou A, Reginald AY, Stavrou P, Kirkby GR. Candida endophthalmitis after tattooing in an asplenic patient. Arch Ophthalmol 2002 Apr;120(4):518-9. DOI PubMed 
36. Horii KA, Jackson MA. Images in clinical medicine. Piercing-related nontuberculous mycobacterial infection. N Engl J Med 2010 May;362(21):2012. DOI PubMed

37. Razavi $B$, Schilling M. Chondritis attributable to Lactobacillus after ear piercing. Diagn Microbiol Infect Dis 2000 May;37(1):75-6. DOI PubMed

38. Satchithananda DK, Walsh J, Schofield PM. Bacterial endocarditis following repeated tattooing. Heart 2001 Jan;85(1):11-2. DOI PubMed

39. Schmidt AN, Zic JA, Boyd AS. Pedicure-associated Mycobacterium chelonae infection in a hospitalized patient. J Am Acad Dermatol 2014 Dec;71(6):e248-50. DOI PubMed

40. Greif J, Hewitt W, Armstrong ML. Tattooing and body piercing. Body art practices among college students. Clin Nurs Res 1999 Nov;8(4):368-85. DOI PubMed

41. Pejcic A, Kojovic D, Mirkovic D. Oral piercing and its complications in two Serbian youths: a case report and review of the literature. West Indian Med J 2012 Nov;61(8):838-43. PubMed

42. Cicchetti S, Skillman J, Gault DT. Piercing the upper ear: a simple infection, a difficult reconstruction. Br J Plast Surg 2002 Apr;55(3):194-7. DOI PubMed

43. Fernandez AP, Neto IC, Anias CR, Pinto PC, de Carvalho E Castro J Carpes AF. Post-piercing perichondritis. Rev Bras Otorrinolaringol (Engl Ed) 2008 Nov-Dec;74(6):933-7. DOI PubMed

44. Fisher CG, Kacica MA, Bennett NM. Risk factors for cartilage infections of the ear. Am J Prev Med 2005 Oct;29(3):204-9. DOI PubMed

45. Akkus NI, Mina GS, Fereidoon S, Rajpal S. Tattooing complicated by multivalvular bacterial endocarditis. Herz 2014 May;39(3):349-51. DOl PubMed

46. Callejo RM, Nacinovich F, Prieto MA, Lambert S, Vizzotti C, Villar HE, Sztejfman M, Navia D, Stamboulian D. Moraxella lacunata infective endocarditis after tattooing as confirmed by $16 \mathrm{~S}$ rRNA gene sequencing from heart valve tissue. Clin Microbiol Newsl 2010;32(1):6-7. DOI

47. Balasekaran R, Bulterys $M$, Jamal MM, Quinn PG, Johnston DE, Skipper B, Chaturvedi S, Arora S. A case-control study of risk factors for sporadic hepatitis $C$ virus infection in the southwestern United States. Am J Gastroenterol 1999 May;94(5):1341-6. DOI PubMed

48. Delage G, Infante-Rivard C, Chiavetta JA, Willems B, Pi D, Fast M. Risk factors for acquisition of hepatitis $C$ virus infection in blood donors: results of a case-control study. Gastroenterology 1999 Apr;116(4):893-9. DOI PubMed

49. Elmukashfi TA, Elkhidir IM, Ibrahim OA, Bashir AA, Elkarim MA. Past medical history of blood transfusion, surgical operation, vaccination against HBV, cutter scar and tattoo; and HBV infection among health care workers in Public Teaching Hospitals in Khartoum State, Sudan. Sudan J Public Health 2012;7(1):7-11. http://khartoumspace.uofk. edu/123456789/16302

50. Khan G, Rizvi TA, Blair I, Adrian TE. Risk of blood-borne infections in barber shops. J Infect Public Health 2010;3(2):88-9. DOI PubMed

51. Pourahmad M, Javady A, Karimi I, Ataei B, Kassaeian N. Seroprevalence of and risk factors associated with hepatitis B, hepatitis $C$, and human immunodeficiency virus among prisoners in Iran. Infect Dis Clin Pract 2007;15(6):368-72. DOI
52. Sharifi-Mood B, Khosravi S. Tattooing: A major source for viral infection. Journal of Medical Sciences 2006;6(4):678-80. DOI

53. Alexandridou A, Reginald AY, Stavrou P, Kirkby GR. Candida endophthalmitis after tattooing in an asplenic patient. Arch Ophthalmol 2002 Apr;120(4):518-9. DOI PubMed

54. Garbaccio JL, de Oliveira AC. Adherence to and knowledge of best practices and occupational biohazards among manicurists/ pedicurists. Am J Infect Control 2014 Jul;42(7):791-5. DOI PubMed

55. Johnson IL, Dwyer JJ, Rusen ID, Shahin R, Yaffe B. Survey of infection control procedures at manicure and pedicure establishments in North York. Can J Public Health 2001 Mar-Apr;92(2):134-7. PubMed

56. Mutocheluh M, Kwarteng K. Knowledge and occupational hazards of barbers in the transmission of hepatitis B and C was low in Kumasi, Ghana. Pan Afr Med J 2015 Mar;20:260. DOI PubMed

57. Shah HB, Dar MK, Jamil AA, Atif I, Ali RJ, Sindhu AS, Usmani AQ. Knowledge, attitudes and practices of hepatitis $b$ and $c$ among barbers of urban and rural areas of Rawalpindi and Islamabad. J Ayub Med Coll Abbottabad 2015 Oct-Dec;27(4):832-6. PubMed

58. Weber AM. Evaluation of potential bloodborne pathogen exposures among body piercers. Appl Occup Environ Hyg 2001 Oct;16(10):925-35. DOI PubMed

59. Government of Newfoundland and Labrador. SNL2012 Chapter P-7.2: Personal Services Act. Amended: Chapter P-7.2: An Act To Regulate The Personal Services Industry. Assented to Jun 272012. https://www.assembly.nl.ca/Legislation/sr/statutes/p07-2.htm

60. Prince Edward Island Health and Wellness Chief Public Health Office. Guidelines for tanning salon owners and operators, 2011. Prince Edward Island Health and Wellness. Charlottesville (PE) Dec 2011 [cited 2018 Oct 29]. http://www.gov.pe.ca/photos/original/ dhw_cpho_tangui.pdf

61. Prince Edward Island Legislative Counsel Office. Public Health Act. Updated 2018 June 12. https://www.princeedwardisland.ca/sites/ default/files/legislation/P-30-1-Public\%20Health\%20Act.pdf

62. Cosmetology Association of Nova Scotia. Salon and spa compliance handbook. Halifax (NS): Cosmetology Association; [cited 2018 Oct 29]. https://www.nscosmetology.ca/images/pdf/salon-permits/ Salon_Compliance_Handbook.pdf

63. Nova Scotia Legislature. Bill No. 109. Government Bill: Safe Body Art Act: Chapter 44 of the Acts of 2011 [2011 Dec 15]. https:// nslegislature.ca/legc/bills/61st_3rd/3rd_read/b109.htm

64. Legislature NS. Health Protection Act. Chapter 4 of the Acts of 2004 as amended by 2010 , c. 41 , s. $112 ; 2014$, c. 32, ss. 122-126. https://nslegislature.ca/sites/default/files/legc/statutes/health\%20 protection.pdf

65. Executive council of Nova Scotia. Safe Body Art Regulations. Approved by Order in Council March 6 2018. [effective on and after February 1, 2019] https://www.novascotia.ca/just/regulations/ regs/2018-39.pdf

66. Legislative Assembly of New Brunswick. Bill 56 Public Health Act (1998). https://www.gnb.ca/legis/business/pastsessions/53/53-3/ status-e/bills/056-e.asp

67. Ministère de la Santé et des services sociaux, Québec. Tattooers and piercers: protect your client and yourself against HIV and hepatitis B and C. Québec (QE): Government of Quebec; 1999. http:// publications.msss.gouv.qc.ca/msss/fichiers/2002/02-310-02A.pdf 
68. Infection Prevention and Control Best Practices for Personal Services Settings. Infection Prevention and Control Unit, Public Health Division, Ministry of Health and Long-Term Care. Toronto (ON) 2009 Jan. http://www.ontla.on.ca/library/repository/mon/23007/293929. pdf

69. Infection Prevention and Control Disclosure Protocol, 2018. Population and Public Health Division, Ministry of Health and Long-Term Care. Toronto (ON) 2018 Jul 1. http://www.health. gov.on.ca/en/pro/programs/publichealth/oph_standards/docs/ protocols_guidelines/Infection_Prevention_and_Control_Disclosure_ Protocol_2018_en.pdf

70. Infection Prevention and Control Complaint Protocol, 2018. Population and Public Health Division, Ministry of Health and Long-Term Care. Toronto (ON) 2018 Jan 1. http://healthunit.org/wpcontent/uploads/IPAC_Complaint_Protocol_2018.pdf

71. Personal Service Settings Guideline. 2018. Queen's Printer for Ontario. Population and Public Health Division, Ministry of Health and Long-Term Care. Toronto (ON) [effective $2018 \mathrm{Jul}$ ] Publication No. 978-1-4868-2427-4 http://health.gov.on.ca/en/pro/programs/ publichealth/oph_standards/docs/protocols_guidelines/Personal_ Service_Settings_Guideline_2018_en.pdf

72. Protecting and Promoting the Health of Ontarians. Ontario Public Health Standards: Requirements for Programs, Services, and Accountability. Ministry of Health and Long-Term Care. Toronto (ON) [effective 2018 Jan 1; revised 2018 Jul 1]. http://www.health. gov.on.ca/en/pro/programs/publichealth/oph_standards/docs/ protocols_guidelines/Ontario_Public_Health_Standards_2018_ en.pdf

73. Government of Ontario. O. Reg. 136/18: Personal Service Settings filed March 29, 2018 under Health Protection and Promotion Act, R.S.O. 1990, c. H.7. https://www.ontario.ca/laws/regulation/180136

74. Manitoba Health. Personal Service Facility Guidelines. Manitoba Health. Winnipeg (MB) 2013 Nov. https://www.gov.mb.ca/health/ publichealth/environmentalhealth/protection/docs/psf_guideline.pdf

75. Saskatchewan Personal Service Facility Best Management Practices. Government of Saskatchewan. Regina (SK) 2014 Jul 2. http:// publications.gov.sk.ca/documents/13/108743-Saskatchewan\%20 Personal\%20Service\%20Facility\%20Best\%20Management\%20 Practices.pdf

76. Government of Saskatchewan. The Health Hazard Regulations being Chapter P-37.1 Reg 10 (effective December 5, 2002) as amended by Saskatchewan Regulations 57/2007 and 81/2015.2015. http://www. qp.gov.sk.ca/documents/english/regulations/regulations/p37-1r10. pdf

77. Health Standards and Guidelines for Tattooing. Edmonton (AB): Alberta Health and Wellness; 2002 Jun. https://open.alberta. ca/dataset/608c49f9-1378-41d6-aec8-8637c85bea01/resource/ fc1d7b21-15d8-49e0-8b07-aebea02de5e1/download/standardstattooing.pdf

78. Health Standards and Guidelines for Body and Ear Piercing. Alberta Health and Wellness. Edmonton (AB) 2002 Jun. https:// open.alberta.ca/dataset/987840a6-1ace-4123-952c-41a5cf4fff74/ resource/23d5976f-6d68-4ec1-91e9-4113c3c381af/download/ standards-body-ear-piercing.pdf

79. Health Standards and Guidelines for Barbering and Hairstyling. Alberta Health and Wellness. Edmonton (AB) 2002 Jun. https:// open.alberta.ca/dataset/82d5da54-27ea-4494-b809-03f441e988e7/ resource/a6b34ebe-0899-43da-a074-6de113ef94fa/download/ standards-barber-hairstyling.pdf

80. Health Standards and Guidelines for Esthetics. Alberta Health and Wellness. Edmonton (AB) 2002 Jun. https://open.alberta.ca/dataset/ af4309b7-85fd-40e2-9f9a-6eeefba6d261/resource/66d43fe8-be2d4528-92df-258b1d12c429/download/standards-esthetics.pdf

81. Health Standards and Guidelines for Electrolysis. Alberta Health and Wellness. Edmonton (AB) 2002 Jun. https://open.alberta.ca/dataset/ ced35e24-96ab-433d-a5fe-bb11a7207ebc/resource/243608062350-495c-ae66-a547c20a5284/download/standards-electrolysis.pdf

82. Province of Alberta. Public Health Act Personal Services Regulation. Alberta Regulation 20/2003. With amendments up to and including Alberta Regulation 127/2016. http://www.qp.alberta.ca/documents/ Regs/2003_020.pdf

83. Guidelines for Personal Services Establishments, November 2017. Victoria (BC): Health Protection Branch, Ministry of Health, British Columbia; 2017 Nov. https://www2.gov.bc.ca/assets/gov/health/ keeping-bc-healthy-safe/pses/pse_guidelines_final_nov_2017.pdf

84. Guidelines for Body Modification, November 2017. Victoria (BC): Health Protection Branch, Ministry of Health, British Columbia; 2017 Nov. https://www2.gov.bc.ca/assets/gov/health/keeping-bc-healthysafe/pses/body_modification_guidelines_nov_2017.pdf

85. Guidelines for Personal Services Offered at Tradeshows. The Personal Service Establishments Working Group Victoria (BC): Health Protection Branch, Ministry of Health, British Columbia; 2016 Jun. https://www2.gov.bc.ca/assets/gov/health/keeping-bc-healthy-safe/ pses/tradeshow_guidelines_june_2016.pdf

86. Guidelines for Floatation Tanks, January 2016. Victoria (BC): Health Protection Branch, Ministry of Health, British Columbia; 2016 Jan. https://www2.gov.bc.ca/assets/gov/health/keeping-bc-healthy-safe/ pses/floatation_tank_guidelines_jan_2016.pdf

87. Laser Hair Removal Devices: Safety Guidelines for Owners/ Operators. BC Centre for Disease Control. Victoria (BC): BC Centre for Disease Control; 2005 Sep. https://www.health.gov.bc.ca/library/ publications/year/2011/Laser-hair-removal-guidelines.pdf

88. Microblading Services in Personal Service Establishments. Fact Sheet for Operators. BC Ministry of Health. Victoria (BC): BC Ministry of Health; 2017 Aug. https://www2.gov.bc.ca/assets/gov/health/ keeping-bc-healthy-safe/pses/microblading_factsheet_final_eho_ operator_aug2_2017.pdf

89. BC Laws. B.C. Reg. 161/2011. O.C. 423/2011 Public Health Act. Regulated activities regulation [includes amendments up to B.C Reg. 286/2012, October 15, 2012]. http://www.bclaws.ca/civix/ document/id/loo99/loo99/161_2011

90. Yukon Health \& Social Services Environmental Health Services. Personal Service Premises Inspection Model. September 2013 Whitehorse (YK): Yukon Health \& Social Services; 2013. http://www. hss.gov.yk.ca/pdf/pspremisesinspectionmodel.pdf

91. Government of Yukon. O.I.C. 1984/124 Public Health Act. Yukon Regulations. Personal Service Establishment Regulations. http:// www.gov.yk.ca/legislation/regs/oic1984_124.pdf

92. Northwest Territories Standards for Personal Service Establishments PSE's. Yellowknife (NT): Chief Public Health Office, Northwest Territories; 2012. https://www.hss.gov.nt.ca/sites/hss/files/nwt-psestandards.pdf 
93. Legislation Division, Department of Justice, Government of Northwest Territories. Public Health Act. Personal Service Establishment Regulations R-064-2012. Amended by R-083-2018, in force May 15, 2018. Yellowknife (NT): Government of Northwest Territories. https://www.justice.gov.nt.ca/en/files/legislation/publichealth/public-health.r1.pdf

94. Legislation Division, Department of Justice, Government of Nunavut. Chapter 13. Public Health Act. (Assented to November 8, 2016). https://www.nunavutlegislation.ca/en/statutes-of-nunavut/2016

95. Barber Shops and Beauty Salons Regulations. RRNWT (Nu) $1990 \mathrm{c}$ P-11. Nunavut. 1990. https://www.canlii.org/en/nu/laws/regu/rrnwtnu-1990-c-p-11/latest/rrnwt-nu-1990-c-p-11.html

96. Centre for Communicable Diseases and Infection Control. Routine practices and additional precautions for preventing the transmission of infection in healthcare settings. Ottawa (ON): Public Health Agency of Canada; [modified 2017 Sep 26]. https://www.canada.ca/ en/public-health/services/publications/diseases-conditions/routinepractices-precautions-healthcare-associated-infections.html
97. Centre for Communicable Diseases and Infection Control. Hand hygiene practices in healthcare settings. Ottawa (ON): Public Health Agency of Canada; 2012. https://www.canada.ca/en/public-health/ services/infectious-diseases/nosocomial-occupational-infections/ hand-hygiene-practices-healthcare-settings.html

98. Ontario Agency for Health Protection and Promotion (Public Health Ontario), Provincial Infectious Diseases Advisory Committee. Best Practices for Environmental Cleaning for Prevention and Control of Infections in All Health Care Settings, $3^{\text {rd }}$ Edition. Toronto, ON: Queen's Printer for Ontario, Apr 2018. https:// www.publichealthontario.ca/en/eRepository/Best_Practices_ Environmental_Cleaning.pdf

99. Spaulding E. The role of chemical disinfection in the prevention of nosocomial infections. In: Proceedings of the International Conference on Nosocomial Infections, 1970. Chicago (IL): American Hospital Association; 1971. pp. 247-54
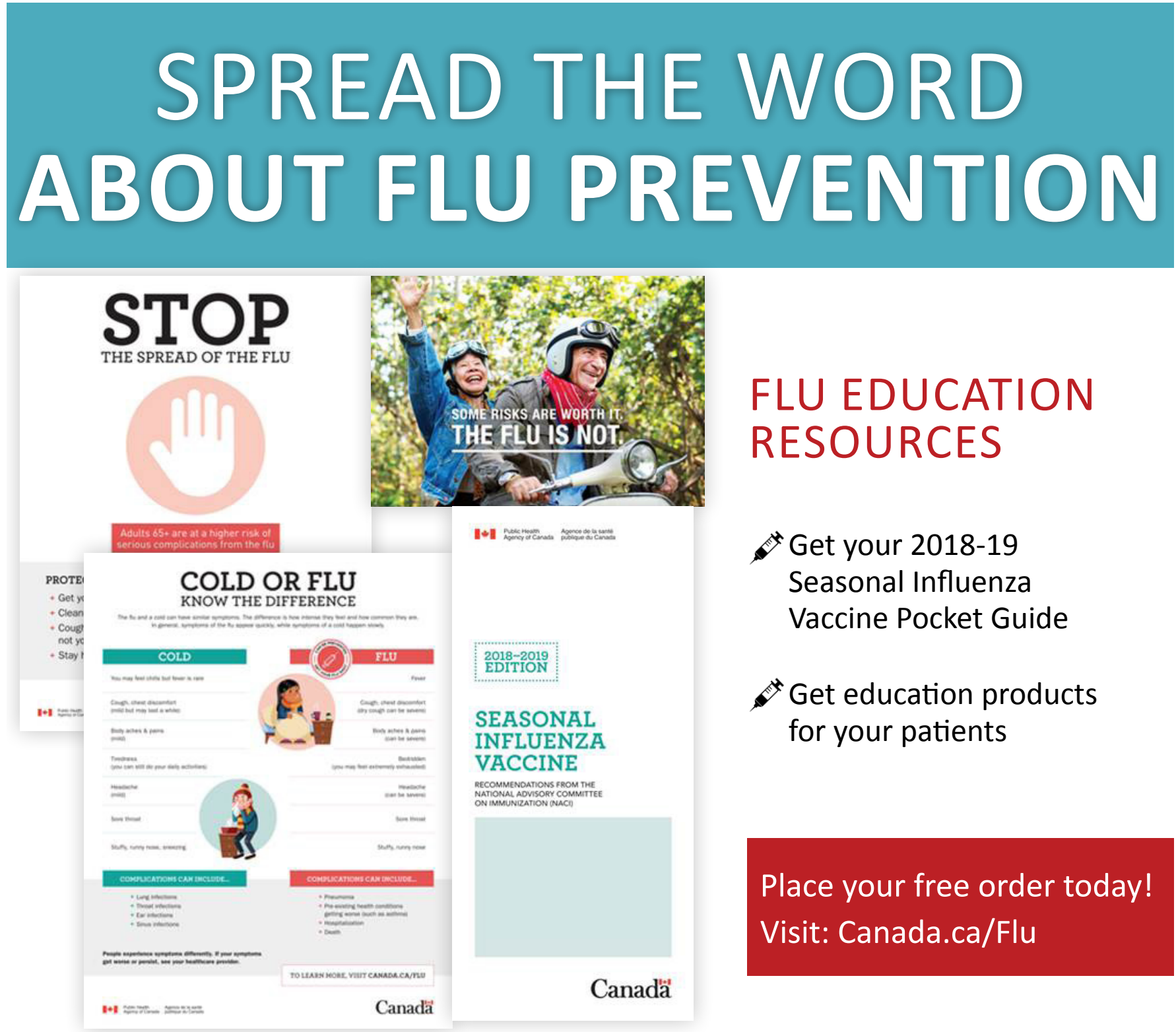

\section{FLU EDUCATION RESOURCES}

\author{
Get your 2018-19 \\ Seasonal Influenza \\ Vaccine Pocket Guide
}
Get education products for your patients

\section{Place your free order today! Visit: Canada.ca/Flu}

